Radomir Jovanović, pukovnik, dipl. inž. dr Vasilije Mišković, pukovnik, dipl. inž. Vojna akademija-ŠNO,
Beograd

\section{TRANSPORTNI SISTEM U FUNKCIJI \\ ODBRANE ZEMLJE}

\author{
UDC: 656 : 355.45 "364"
}

Rezime:

Transportni sistem zemlje postoji i funkcioniše u miru, a od izuzetnog značaja je za odbranu zemlje. Uticaj ovog sistema na odbranu nije samo direktan, nego i indirektan, jer skoro svi sistemi uključeni u ovaj proces zavise od njega. U odnosu na mirnodopsko stanje, osnovna karakteristika funkcionisanja transportnog sistema u ratu je izvršavanje zadataka $u$ uslovima razaranja infrastrukture, višestrukog povećanja transportnih zahteva i neprekidna izloženost udarima svih elemenata sistema. Zato su pripreme za funkcionisanje u takvim uslovima od izuzetnog značaja.

Ključne reči: odbrana, transportni sistem, transportni zahtevi.

\title{
THE TRANSPORTATION SYSTEM IN FUNCTION OF DEFENSE OF COUNTRY
}

Summary:

The transportation system of a country exists and functions in peace and it is very important for the defense of the country. The transportation system has not only direct but also indirect influence on defense, because almost all systems included in defense are dependent on it. When compared to peace, the basic characteristics of its functioning in war is carrying out the tasks in conditions of infrastructure destruction, multiplied transportation demands and continuous blow of all elements of the system. For all these reasons the preparations for transportation system functioning in those conditions are of exceptional importance.

Key words: defense, transportation system, transportation demands.

\section{Uvod}

Sistem odbrane zemlje je nezamenljiv činilac stabilnosti i napretka društvene zajednice. Razvijen u snažan sistem, on deluje kao faktor sigurnosti, zaštite i očuvanja slobode, života u miru, stečenih tekovina napretka i stvaranja novih vrednosti.

U sistemu odbrane zemlje uz efikasnu organizaciju koncentrišu se najvitalnije snage, najsavremenija sredstva i tehnologije. Ulaganje u takav sistem ima vi- šestruke pozitivne razvojne, ekonomske i opšte društvene efekte.

Odbrana zemlje, kao jedna od oblasti društvenih odnosa, uređuje se najvišim pravnim aktom, ustavom, čime je ona jedan od bitnih elemenata državne organizacije i ima značajno mesto $u$ ustavno-pravnoj regulativi države, gde se razmatra kao konstantna društvena potreba i ostvaruje na način kako to zahtevaju međunarodne političke prilike i situacija u zemlji. 
Sistem odbrane, kao kompleks operativnih opredeljenja, mera i aktivnosti, pretežno se bavi izgradnjom snaga i sredstava i razradom metoda delovanja koji državu i društvo štite od direktnog ugrožavanja, pri čemu se oslanja na sopstvene materijalno-tehničke i ljudske resurse.

Snaga odbrane, kao ukupna moć koju društvo može da ispolji u pružanju otpora agresoru, definisana je kroz ljudske i materijalne mogućnosti zemlje.

Materijalne mogućnosti ispoljavaju se u sposobnosti zemlje da u celokupnom toku rata obezbedi i podmiri neophodne potrebe borbenih i drugih materijalnih sredstava (MS) u pogledu njihove vrste, kvaliteta i obima za sve vidove odbrambenih aktivnosti i za potrebe stanovništva zemlje.

Postojanje MS samo po sebi nije dovoljno; nužno je da ona budu stavljena na raspolaganje neposrednim korisnicima $i$ to $u$ vremenu kada je to potrebno. Pored toga, za efikasnu odbranu potrebno je omogućiti pokret i manevar, kako jedinica tako i MS. Bez saobraćajnog i transportnog sistema to nije moguće.

\section{Karakteristike sistema odbrane}

Opšti odbrambeni cilj zemlje jeste izgradnja pouzdanog, fleksibilnog i celovitog sistema odbrane od svih oblika nevojnih i vojnih pretnji bezbednosti, radi očuvanja slobode, nezavisnosti, suvereniteta i teritorijalnog integriteta, odvraćanjem ili suprotstavljanjem silom, u zavisnosti od oblika ugrožavanja [2].

Shodno svom opredeljenju, državna zajednica Srbija i Crna Gora organizovala je takav sistem odbrane u koji su uključeni svi subjekti društva: građani,
Vojska, državni organi i organizacije, organi i organizacije lokalne samouprave, ustanove i organizacije koje obavljaju javnu službu ili delatnost, preduzeća i druga pravna lica [3].

Svi subjekti svoje obaveze izvršavaju u okviru jedinstvenog državnog sistema, čiji je osnovni i jedini nosilac i koordinator državna zajednica SCG, što se izražava, pre svega, u jedinstvenoj pravnoj regulativi koja je u nadležnosti: Skupštine Srbije i Crne Gore, Vrhovnog saveta odbrane, Saveta ministara i Ministarstva odbrane. Pored toga, državna zajednica SCG je, preko svojih organa i Vojske, nosilac, organizator i koordinator funkcija sistema odbrane u svim njegovim elementima, a to su:

- preduzimanje odbrambenih mera: dovođenje snaga odbrane - Vojske, odnosno društva u stanje gotovosti za izvršavanje zadataka u odbrani zemlje; utvrđivanje stanja ugroženosti odbrane zemlje (stanja neposredne ratne opasnosti, ratnog stanja, vanrednog stanja); izvršenje mobilizacije; preduzimanje mera pripravnosti;

- organizovanje i izvršavanje zadataka snaga odbrane koje se sastoje od ukupnog ljudskog i materijalnog faktora Vojske SCG, snaga ministarstava unutrašnjih poslova Srbije i Crne Gore i civilne zaštite;

- obavljanje svih poslova odbrane; obavljaju ih određeni državni organi (Skupština SCG, Savet ministara, Vrhovni savet odbrane, Ministarstvo odbrane) i nadležni organi Vojske.

Jedinstvo sistema odbrane izražava se u ulozi Vojske SCG koja je glavna oružana sila i nosilac oružane borbe i svih drugih organa oružanog suprotstavljanja neprijatelju. 
Uspešno vođenje rata u svim uslovima agresije osnovni je zadatak sistema odbrane. On se ostvaruje: jedinstvenim i efikasnim rukovođenjem i komandovanjem; potpunom osposobljenošću i pripremljenošću snaga odbrane; izborom oblika suprotstavljanja agresiji i uspešnom vođenju oružane borbe do pobede nad agresorom.

Kao podsistem velikog državnog sistema, na sistem odbrane utiču svi drugi sistemi (ekonomski, politički, pravni i dr.), na koje mnogobrojne uticaje ispoljava međunarodna zajednica.

Karakteristike sistema odbrane SCG zasnovane su na osnovnim doktrinarnim načelima koja još uvek nisu u potpunosti uobličena i zakonski ozvaničena. Sistem odbrane SCG vrlo je dinamičan, hijerarhijski ustrojen, otvoren i izuzetno složen. On u praksi funkcioniše uz niz poteškoća normativno-pravne, političke, organizacione i ekonomske prirode.

Globalno, strategijske sisteme odbrane čine [4]:

- subjekti koji odlučuju o njegovoj organizaciji i koji rukovode i upravljaju sistemom (državno i vojno rukovodstvo);

- ciljevi i zadaci koje sistem ostvaruje;

- oružane snage i civilna odbrana;

- prostor i vreme u kojima sistem funkcioniše;

- doktrina i strategija ponašanja sistema;

- delatnosti, aktivnosti i funkcije koje se odvijaju u sistemu i u njegovom okruženju.

Sistem odbrane SCG čine njegovi bitni elementi: odbrambene aktivnosti; odbrambene mere; snage odbrane; poslovi odbrane; subjekti odbrane. To su bitni (konstitutivni) elementi sistema odbrane, jer bez postojanja bilo kojeg od njih sistem ne bi funkcionisao kao celovit.

Odbrambene aktivnosti sastoje se od sledećih oblika suprotstavljanja neprijatelju (vidova odbrambenih aktivnosti): oružane borbe; neoružanih oblika borbe i otpora; bezbednosti i zaštite odbrane; civilne odbrane i zaštite i službe osmatranja i obaveštavanja.

Odbrambene mere su radnje i postupci koji se preduzimaju sa ciljem da se snage odbrane i čitavo društvo u celini dovedu u stanje gotovosti za ostvarivanje odbrambenih aktivnosti $u$ odbrani zemlje. Reč je o takvim radnjama i postupcima kojima se ,adekvatno reaguje na određene opasnosti po zemlju“".

Snage odbrane, u užem smislu, posebno su organizovane i adekvatno opremljene i osposobljene za odbrambene aktivnosti. To su: Vojska SCG, Snage ministarstava unutrašnjih poslova republika članica državne zajednice, Bezbednosno-informativna agencija, civilna zaštita i služba osmatranja i obaveštavanja.

Poslovi čije je organizovanje i obavljanje usmereno na razvoj i jačanje društva za odbranu zemlje smatraju se poslovima odbrane u najširem smislu. Oni imaju neposredno odbrambeni značaj, jer im je osnovna svrha organizovanje i osposobljavanje snaga odbrane i društva u celini za odbranu zemlje, i nazivaju se poslovima odbrane.

Subjekti odbrane su oni koji te poslove obavljaju kao svoju redovnu funkciju. Poslovi odbrane organizuju se i vrše u okviru društveno organizovanih celina koje su organizovane na političkom, teritorijalnom, radnom ili nekom drugom principu. 
Rukovođenje sistemom odbrane je sastavni deo opšteg sistema rukovođenja društvenim poslovima $\mathrm{u}$ okviru sistema vlasti na svim nivoima državnog organizovanja. To je redovna funkcija organa koji se bave organizovanjem i pripremanjem funkcionisanja sistema odbrane $u$ celini ili njenih pojedinih delova.

\section{Značaj transportnog sistema za odbranu}

Uspešnost odbrane zemlje funkcionalno zavisi od efikasnosti transportnog sistema zemlje, bez kojeg nema brzog aktiviranja svih potencijala za odbranu i obezbeđenja potrebnih transportnih usluga oružanim snagama, privredi i stanovništvu.

Takođe, efikasno funkcionisanje saobraćajnog sistema Vojske od vitalnog je značaja za sve funkcije vojne organizacije u miru i ratu.

Transportni sistem obezbeđuje aktiviranje svih potencijala odbrane i utiče na efikasnost ostalih sistema odbrane. Njegov odbrambeni značaj ogleda se ne samo u tome što predstavlja materijalnu bazu za prevoženje borbenih jedinica i borbenih sistema, već i zbog mesta transportne funkcije u vojnoj logistici. Činjenica je da su savremena transportna sredstva izuzetno značajna za razvoj i upotrebu velikog broja sredstava naoružanja i opreme, bez čijeg udela njihova upotreba nije moguća ili je bitno umanjena.

Zahtevi koje nameće savremeni rat, koji karakteriše izrazita koncentracija velikog broja motornih vozila, manevarska karakteristika borbenih dejstava, izvanredan značaj faktora brzine i vremena $u$ ratnim operacijama, zavisnost borbenih dejstava od komunikacija i njihova izloženost neprekidnim dejstvima, potreba da se jedinice brzo kreću i premeštaju, potreba za doturom i evakuacijom velikih količina materijalnih sredstava - ističe značaj saobraćaja i dovoljnog transporta. Njihov značaj je još veći ukoliko se u obzir uzmu mogućnosti savremenih borbenih sredstava i sistema i njihova dejstva po elementima saobraćajnog i transportnog sistema koji se ne mogu maskirati i zaštititi.

Sve aktivnosti u periodu pripreme za odbranu, u toku i nakon rata, zasnivaju se na saobraćajnom i transportnom sistemu zemlje. Napad na saobraćajnu infrastrukturu i razaranje njenih sadržaja, na efikasan način neutrališe vojnu i ekonomsku moć protivnika. Zbog toga se saobraćaju i transportu mora posvetiti dužna pažnja na svim nivoima društvene organizovanosti. Oni se moraju neprekidno razvijati i usavršavati sa ciljem da bude dovoljan, neprekidan, brz, uredan, bezbedan, ekonomičan i pouzdan, kako u miru, tako i u ratnim uslovima. Sistem transporta mora se stalno planski razvijati. Elementi razvoja transportnog sistema po dugoročnim, srednjoročnim i godišnjim planovima prikazani su u tabeli [8].

Transport, kao jednu od funkcija logistike, karakterišu složeni organizacioni i tehnološki procesi. Efikasno funkcionisanje transporta od vitalnog je značaja za sve funkcije vojne organizacije u miru i ratu. Jedan od osnovnih ciljeva je da se racionalnim planiranjem, organizacijom i realizacijom transportnog procesa obezbedi realizacija ciljeva i zadataka u svim uslovima, uz minimalan utrošak resursa. 
Elementi i ciljevi razvoja transportnog sistema

\begin{tabular}{|c|c|c|c|}
\hline $\begin{array}{l}\text { Elementi razvoja } \\
\text { transportnog sistema }\end{array}$ & Dugoročni ciljevi (DP) & Srednjoročni ciljevi (SP) & $\begin{array}{l}\text { Godišnji ciljevi razvoja } \\
\text { (GP) }\end{array}$ \\
\hline $\begin{array}{l}\text { Organizacijsko- } \\
\text {-mobilizacijski razvoj }\end{array}$ & $\begin{array}{l}\text { Uraditi prognozu potreba } \\
\text { VSCG za prevoženjima u } \\
\text { miru, MOB periodu i ratu } \\
\text { po organizacionim } \\
\text { jedinicama i strukturi } \\
\text { transporta. Definisati } \\
\text { jedinstveni transportni } \\
\text { sistem VSCG. Povećati } \\
\text { efikasnost mirnodopskog } \\
\text { transporta. }\end{array}$ & \begin{tabular}{|l|} 
Odrediti obim \\
transportnog rada po \\
godinama SP i potrebe \\
preformiranja transportnih \\
jedinica. Podići stručni \\
nivo kadrovske strukture. \\
Utvrditi pravce razvoja \\
dispečerske službe. \\
Osposobiti snabdevačke \\
službe za izvršenje \\
transporta.
\end{tabular} & $\begin{array}{l}\text { Utvrditi obim i stepen } \\
\text { neravnomernosti obrta } \\
\text { tereta na putnoj mreži po } \\
\text { vrstama tereta i nivoima } \\
\text { centralizovanog } \\
\text { transporta. } \\
\\
\end{array}$ \\
\hline Vozni park & $\begin{array}{l}\text { Proučiti pravce razvoja } \\
\text { tehničkog progresa i } \\
\text { industrije transportnih } \\
\text { sredstava. Utvrditi } \\
\text { kriterijum popune } \\
\text { transportnih jedinica. }\end{array}$ & $\begin{array}{l}\text { Odrediti konkretne } \\
\text { zadatke razvoja voznog } \\
\text { parka po tipovima vozila. } \\
\text { Utvrditi potrebu za } \\
\text { komercijalnim vozilima } \\
\text { posebne namene. }\end{array}$ & $\begin{array}{l}\text { Odrediti kriterijume } \\
\text { korišćenja voznog parka. } \\
\text { Utvrditi kapacitete vozila } \\
\text { u stalnoj i privremenoj } \\
\text { eksploataciji. }\end{array}$ \\
\hline $\begin{array}{l}\text { Sredstva integralnog } \\
\text { transporta (IT) } \mathrm{i} \\
\text { manipulacije }\end{array}$ & \begin{tabular}{|l} 
Utvrditi tendencije \\
razvoja sredstava IT i \\
manipulacije i uskladiti \\
sopstveni razvoj. Povećati \\
tehnički nivo procesa \\
manipulacije.
\end{tabular} & $\begin{array}{l}\text { Odrediti potrebna sredstva } \\
\text { po strukturi i broju za } \\
\text { paletizaciju i } \\
\text { kontejnerizaciju. Uskladiti } \\
\text { transportno-manipulativne } \\
\text { jedinice tereta sa } \\
\text { zahtevima IT. }\end{array}$ & $\begin{array}{l}\text { Utvrditi vrste i količine } \\
\text { MTS za ukrupnjavanje i } \\
\text { potreban broj sredstava IT. }\end{array}$ \\
\hline Parkovi motornih vozila & $\begin{array}{l}\text { Utvrditi potrebu za razvoj } \\
\text { infrastrukture u } \\
\text { parkovima motornih } \\
\text { vozila. }\end{array}$ & $\begin{array}{l}\text { Odrediti potrebe u } \\
\text { garažnom prostoru, } \\
\text { nadstrešnicama, } \\
\text { stajankama, servisnim i } \\
\text { kontrolno-propusnim } \\
\text { stanicama. Utvrditi } \\
\text { kriterijume i tipska } \\
\text { rešenja. }\end{array}$ & $\begin{array}{l}\text { Povećati ispravnost } \\
\text { transportnih sredstava. } \\
\text { Uskladiti osnovno i } \\
\text { tehničko održavanje sa } \\
\text { izvršenjem transportnih } \\
\text { zadataka. }\end{array}$ \\
\hline Utovarno-istovarna mesta & $\begin{array}{l}\text { Odrediti pravce razvoja } \\
\text { strukture i organizacije } \\
\text { utovarno-istovarnih i } \\
\text { pretovarnih mesta. } \\
\text { Utvrditi potrebe izgradnje } \\
\text { infrastrukture u dogovoru } \\
\text { sa organima društva. }\end{array}$ & \begin{tabular}{|l|} 
Utvrditi zadatke razvoja, \\
specijalizacije, obima rada \\
i propusne moći utovarno- \\
-istovarnih mesta za \\
potrebe VSCG.
\end{tabular} & $\begin{array}{l}\text { Odrediti i uskladiti obrt } \\
\text { tereta, kapaciteta mesta i } \\
\text { voznih parkova. }\end{array}$ \\
\hline $\begin{array}{l}\text { Resursi - potrošna } \\
\text { sredstva }\end{array}$ & $\begin{array}{l}\text { Sagledati energetske } \\
\text { rezerve potrošnih resursa } \\
\text { (goriva, maziva, i dr.). } \\
\text { Utvrditi strukturu resursa i } \\
\text { značajnost za razvoj i } \\
\text { cenu koštanja. }\end{array}$ & $\begin{array}{l}\text { Odrediti potrebe u } \\
\text { potrošnim resursima. } \\
\text { Opremiti i osavremeniti } \\
\text { dispečersku službu. }\end{array}$ & Sniziti cenu transporta. \\
\hline Naučnoistraživački rad & $\begin{array}{l}\text { Utvrditi pravce naučne } \\
\text { organizacije rada i } \\
\text { upravljanja u } \\
\text { transportnom sistemu } \\
\text { VSCG. }\end{array}$ & $\begin{array}{l}\text { Odrediti program NIR za } \\
\text { organizacijsko- } \\
\text {-formacijski razvoj i } \\
\text { razvoj materijalne baze } \\
\text { vojnog transporta. }\end{array}$ & $\begin{array}{l}\text { Utvrditi naučno- } \\
\text { istraživačke zadatke } \\
\text { razvoja transporta po } \\
\text { ratnoj veštini, sredstvima, } \\
\text { opremi i ekonomici. }\end{array}$ \\
\hline
\end{tabular}


$S$ jedne strane, transport je integralni deo logističke podrške Vojske, a s druge je u funkcionalnom, organizacionom i tehničko-tehnološkom smislu zasnovan na jedinstvenom transportnom sistemu zemlje. Koncipiran je tako da se, pored vlastitih resursa, kojima se obezbeđuje operativna gotovost, oslanja i na transportne organizacije, komunikacije i transportne resurse teritorije, koje se $\mathrm{u}$ određenim situacijama uključuju u funkcionisanje vojnog saobraćaja. Nadležni vojni organi moraju pratiti njihovo stanje, razvojem informacionog sistema obezbediti uvid u stanje ovih resursa i razmenu informacija sa sistemima koji su za njih pravno i funkcionalno nadležni. Takođe, vojni transport realizuje se $\mathrm{u}$ otvorenom sistemu zemlje, na jedinstvenoj i nedeljivoj mreži saobraćajnica svih vidova i grana saobraćaja, koja je neprekidno dostupna svim zainteresovanim kategorijama korisnika.

Transport u Vojsci, kao podsistem transportnog sistema zemlje, složen je, dinamičan, organizaciono i hijerarhijski uređen, sa jasno definisanim nivoima odlučivanja, sa propisanom funkcionalnom i organizacionom strukturom.

\section{Uticaj transporta na sistem odbrane}

Moć sistema odbrane neodvojiva je od tempa ekonomskog razvoja i raspoloživosti proizvodnih faktora (stanovništva, privrednog bogatstva i osnovnih proizvodnih fondova). Upravo je u ekonomskom razvoju sadržan materijalni okvir bezbednosti, i u uslovima ugroženosti bezbednosti zemlje, ekonomski sistem bitno utiče na odbrambenu moć svojim prilagođavanjem potrebama odbrane [6].

Transport, kao privredna oblast, svoju delatnost vezuje za usluge privredi i stanovništvu. U uslovima eventualnog rata, svi vidovi saobraćaja i transporta imaju značajno mesto u pogledu prevoza ljudi i sredstava.

Struktura transportnih sistema formirana je isključivo prema potrebama mirnodopskog razvoja privrede, a na komparativnim prednostima pojedinih grana transporta može biti u dubokom neskladu sa zahtevima odbrane zemlje. U projektovanju transportnog sistema u miru, uvažavanje zahteva odbrane postaje utoliko potrebnije što, za razliku od ostalih delatnosti (koje mogu promeniti proizvodni program, pa i dislocirati svoje kapacitete), ovaj sistem u ratu uglavnom zadržava postojeće mirnodopske elemente. Ukoliko se u miru izgrađuje kao nedovoljno integrisani sistem, $u$ eventualnom ratu neće biti mogućnosti ni vremena za izmenu tog sistema.

Mirnodopska organizacija i razvoj saobraćaja i transporta mora biti identična ili bliska organizaciji u uslovima vođenja rata. Uz uvažavanje ekonomskih kriterijuma u razvoju pojedinih transportnih grana treba uvažavati i činjenicu da su borbena dejstva u osnovi vezana za komunikacije. Samo razvijene i moderno izgrađene komunikacije omogućavaju manevar savremenom ratnom tehnikom, brze pokrete jedinica i njihovo uredno snabdevanje. Sposobnost koncentracije transportnih ratnih sredstava, neophodnih za izvršenje zadataka brzog prevoza i grupisanja jedinica, direktno zavisi od međusobne komplementarnosti pojedinih grana transporta. Jedan od uslova opstan- 
ka transportnih kapaciteta jeste njihova distribuiranost po teritoriji, bez koje bi u savremenom ratu došlo do njihovog masovnog uništavanja. Poremećaji u transportu mogu biti umanjeni izgradnjom zaobilaznih puteva i sporednih železničkih pruga radi povezivanja svih delova zemlje, odnosno ratišta.

Sa stanovišta rata, tehnološko jedinstvo sredstava i opreme u oblasti transporta izuzetno je značajno. Posebno se ističe struktura i kvalitet raspoloživih postrojenja, sredstava i opreme i njihovo funkcionisanje. Prioritet $\mathrm{u}$ strategijskom razvoju trebalo bi da imaju oni programi u kojima se korišćenjem domaće tehnologije uvode savremena vučna sredstva i vozila. Neodložnost pomenutog procesa izraz je postojeće strukture transportnih sredstava i opreme koja u svim granama transporta zaostaje za potrebama. U suprotnom, moglo bi se dogoditi da znatni transportni kapaciteti budu izbačeni iz upotrebe, što se bitno odražava na odbrambenu sposobnost zemlje.

U procesu priprema i sprovođenja mera za funkcionisanje jedinstvenog transportnog sistema zemlje u odbrani postoje nedostaci koji se, uglavnom, odnose na regulativu kojom na jasan način treba da se utvrde nadležnosti, ovlašćenja i sadržaj potreba po nivoima, horizontalnoj i vertikalnoj organizaciji strukture transportnog sistema zemlje. Takođe, transportni sistem nema jedinstven informacioni sistem (ni po podsistemima), što ga čini neefikasnim i neoperativnim, posebno kada se postave zahtevi za masovna prevoženja, brzi manevar i pokrete.

Zakonom o odbrani regulisano je da se pri izradi prostornog i urbanističkih planova, nosioci poslova i investitori pridržavaju posebnih uslova i zahteva pri izboru, izgradnji i razvoju transportnog sistema, i da ga usklade sa potrebama odbrane zemlje.

S obzirom na to da se sistem odbrane zemlje oslanja na sve vidove i grane transportnog sistema, oni treba da budu žilavi, otporni, elastični i prilagodljivi, neprekidni i sposobni da u svakoj situaciji obezbede osnovne potrebe svih komponenti odbrane.

Da bi se ostvarili zahtevi, transportni sistem mora još u miru da obezbedi odgovarajuće pripreme koje moraju da postanu redovne aktivnosti njegovog mirnodopskog funkcionisanja. U uslovima eventualnog rata, svi vidovi saobraćaja imaće značajno mesto u pogledu prevoza ljudi i sredstava.

Vidovi, grane i vrste saobraćaja i transporta prikazani su na slici 1 .

Putni transport, zbog svojih opštih osobina i mogućnosti prilagođavanja ratnim uslovima, dobija dominantnu ulogu. Prednosti nad drugim granama transporta izražene su postojanjem putne mreže i infrastrukture na celoj teritoriji, a pruža se mogućnost izbora transportnih sredstava, čime ona postaju upotrebljiva $u$ svakoj zemljišnoj, atmosferskoj, vremenskoj i operativno-taktičkoj situaciji.

Putni transport može se odvijati na putevima svih kategorija, na nekategorisanim putevima, pa i van puteva, što omogućava izvršavanje svih zadataka. Odlikuje se elastičnošću, brzinom i skoro potpunom nezavisnošću od drugih grana transporta. Manje je osetljiv i relativno lako i brzo mogu se otkloniti posledice dejstva neprijatelja. 


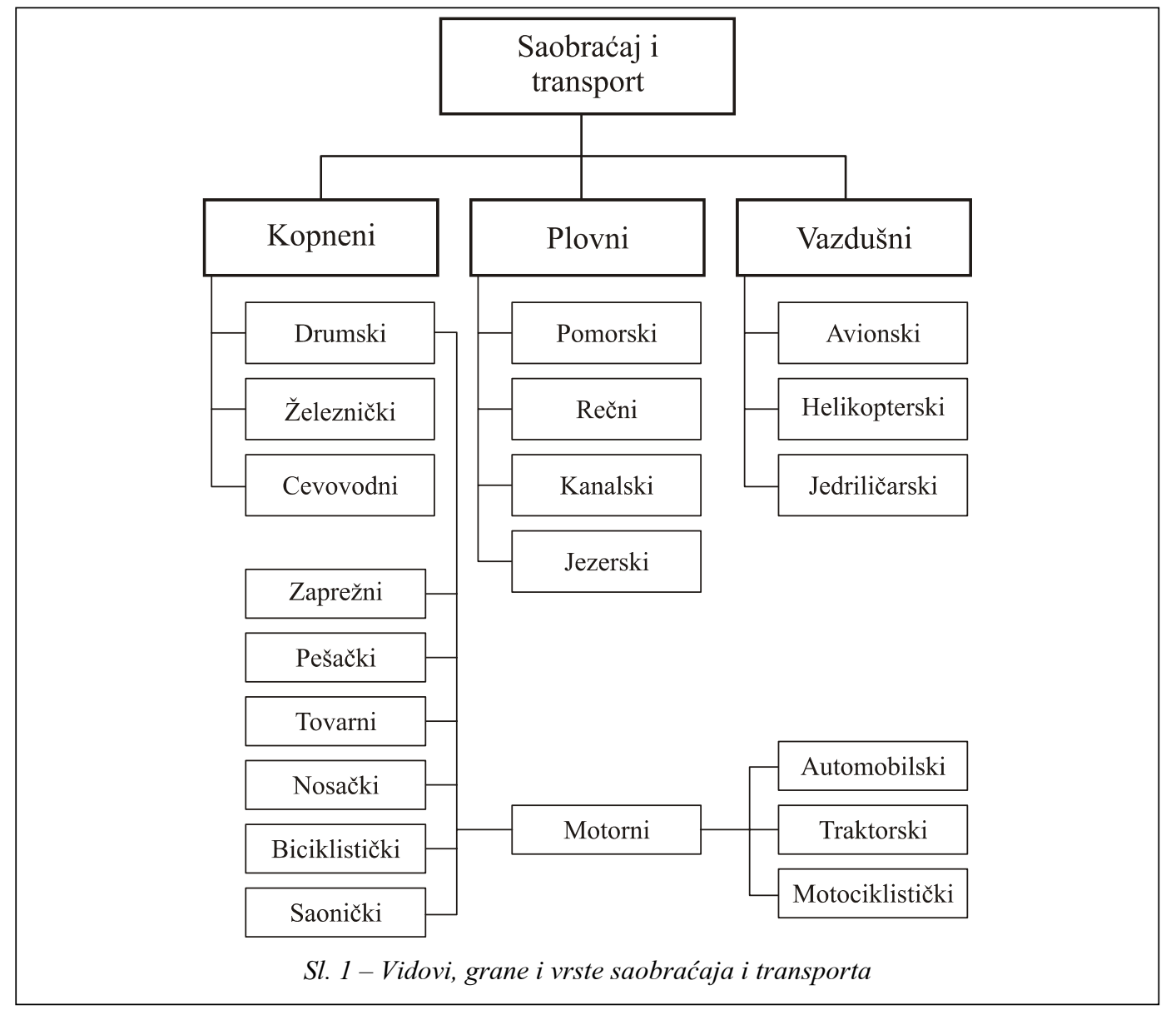

Nedostaci putnog transporta su: zavisnost od atmosferskih uslova, doba dana $\mathrm{i}$ godine $\mathrm{i}$ nepodesnost za masovno prevoženje teških tereta.

Sa početkom rata, a još više u toku borbenih dejstava, može se očekivati da će doći do presecanja železničkih pruga i dužeg ili kraćeg prekida ove grane transporta. U tom slučaju putni transport, kao veoma prilagodljiv potrebama korisnika, moraće da preuzme i deo tereta planiranog za prevoženje železnicom, što ističe i potrebu blagovremenog razvoja putnog saobraćaja i transporta. Struktura komunikacione mreže, formirane isključivo prema potrebama mirnodopskog razvoja privrede, može biti u neskladu sa zahtevima eventualnog rata [7].

Pri projektovanju ukupne infrastrukture u miru, uvažavanje zahteva jačanja odbrambene sposobnosti postaje utoliko potrebnije, za razliku od ostalih delatnosti, zato što transportni sistem zadržava sve elemente mirnodopskog stanja i trpi neznatne promene.

Nedovoljnu elastičnost prilagođavanja u ratu transportni sistem pokazuje i $\mathrm{u}$ pogledu uspostavljanja tehnološkog jedinstva. Ukoliko celokupan vozni park nije usklađen sa karakteristikama železničkih 
pruga na celoj mreži železnice nema ni govora o uspostavljanju jedinstva transporta $\mathrm{u}$ eventualnom ratu. U suštini, sistem koji se u miru potvrđuje kao neefikasan i društveno neracionalan ne može pretendovati na veću organizovanost i osposobljenost za funkcionisanje u ratnim uslovima.

Komplementarnost i homogenost putne mreže obezbeđuje se razvojem magistralne mreže puteva, kao „kičme“ saobraćajnog sistema, ali i dodatnih kapaciteta regionalnog saobraćaja, prvenstveno u brdsko-planinskim područjima, jer se bez njih ne može ostvarivati povezivanje svih delova teritorije. Istovremeno, mora se obezbediti i njihovo povezivanje sa sistemima evropskih putnih pravaca. Jedna od pretpostavki jedinstva transportnog sistema jeste tehnička opremljenost $\mathrm{i}$ tehnološko jedinstvo sistema.

Savremena sredstva i oprema, uz modernizovanu mrežu puteva, uslov su najšireg angažovanja stanovništva i materijalnih dobara u odbrani zemlje. Raspoloživa sredstva i oprema zasnovani su na inostranim tehnologijama, neselektivno su uvoženi, tako da je danas u upotrebi veliki broj tipova raznih vrsta sredstava i opreme, što može imati negativne posledice. Sa stanovišta rata, stanje tehnološkog razvoja u oblasti transporta izuzetno je značajno. U tom smislu, potrebna je izgradnja savremenog sistema za manipulisanje teretima. Reč je o potrebi razvoja različitih vrsta sredstava koja se zaokružuju u jedinstven sistem integralnog transporta, čime transportni sistem postaje znatno racionalniji, a povećava se i njegova ekonomska efikasnost. Racionalnost je bitna karakteristika transportnog procesa u ratu, posebno kada se zna da je prenošenje težišta i izvršenje mane- vra u borbenim dejstvima u uskoj vezi i sa sposobnostima transportnog sistema Vojske, da prevoženjima neophodnih energenata rata prati borbena dejstva.

Transportni sistem Vojske, iako autonoman, treba razvijati u miru u skladu sa razvojem jedinstvenog transportnog sistema zemlje, sa specifičnom transportnom organizacijom koju zahtevaju potrebe Vojske. Ukoliko bi se, pri projektovanju transportnog sistema, potpunije uvažavali zahtevi prevoza u eventualnom ratu, mogla bi se, u znatnoj meri, isključiti potreba za paralelnim razvojem odgovarajućeg sistema u Vojsci.

U pogledu razvoja domaće tehnologije, prioritet bi trebalo da imaju oni programi kojima se uvode savremena vučna sredstva i vozila, radi obezbeđenja međusobne zamenljivosti agregata $\mathrm{i}$ istovrsnih delova, sprovođenjem tipizacije i unifikacije.

Nove transportne tehnologije sve više uslovljavaju specijalizaciju transportnih sredstava i opreme, pa je pri planiranju njihove nabavke neophodno sagledati organizaciju transporta u svim njegovim elementima, pri čemu su od posebnog značaja integralni sistemi (paletni, kontejnerski, Ro-Ro, hucke-rack i drugi transportni sistemi). Prelazak na nove sisteme prevoza karakteristika je sadašnjeg vremena u čemu se u našoj zemlji zaostaje. I u svim drugim granama transporta treba obezbediti upotrebu savremene tehnologije koja će se uklopiti u postojeće standarde i obezbediti konkurentnost $u$ pomorskom, rečnom, vazdušnom, železničkom i putnom transportu, kako u putničkom, tako i u transportu roba.

U odbrani zemlje transport, kao funkcija logističke podrške, ima poseban 
značaj. Sistem saobraćajne podrške (SbP) predstavlja faktor povezivanja i aktiviranja svih komponenti odbrane, omogućava im da dođu do punog izražaja i izvrše svoje zadatke u ratu.

Transport u miru predstavlja faktor materijalne proizvodnje sa osnovnim ciljem da omogući odvijanje procesa društvene reprodukcije u svim oblastima. U ratu tu funkciju zadržava, ali kao jedan od bitnih faktora odbrane svoje funkcije prvenstveno podređuje zadacima vođenja rata $\mathrm{i}$ obezbeđenja efikasnog sistema odbrane zemlje. Transport treba da zadovolji niz potreba, kao što su prevoženja u privredi, društvenim službama i snabdevanju stanovništva, i tako se omogući život u ratu. Istovremeno, treba omogućiti Vojsci i drugim snagama odbrane sve potrebe za prevoženjima, a to su specifični i veoma složeni zadaci koje transportni sistem zemlje u miru ne izvršava u tom obimu.

Funkcije sistema saobraćajne podrške prikazane su na slici 2 [8].

Kada zemlja prelazi na ratno stanje, povećani su zahtevi svih struktura društva, pa i Vojske. Brojni i složeni pokreti jedinica, raseljavanje ratnih materijalnih rezervi i disperzija materijalnih sredstava, masovnost dotura i evakuacije i veliki broj raznovrsnih transportnih zadataka moći će da se izvrši, pre svega, preko jedinstvenog transportnog sistema zemlje. Pri tome se nameće problem kako uskladiti odnose i naći optimalno rešenje $u$ tom jedinstvenom sistemu između nastalih potreba i mogućnosti sistema. Neophodno je formirati adekvatne organe za koordinaciju i usaglašavanje odnosa na raznim nivoima odlučivanja radi rešavanja složenih i brojnih problema.
Neke karakteristike savremenih ratova mogu se prepoznati i u događanjima u poslednjoj dekadi XX veka na prostorima SFRJ, a posebno u agresiji NATO-a na SR Jugoslaviju. Korišćenjem najnovijih tehnologija proizveden je čitav spektar novih borbenih sistema i ubojnih sredstava koji imaju veliki uticaj na fizionomiju savremenog rata.

Logistika Vojske poseban je sistem kroz koji se usklađuju odnosi, organizacija i angažovanje logističkih službi, i tako ostvaruje logistička podrška komandi, jedinica i ustanova. Logistička podrška predstavlja operacionalizaciju opštih postavki teorije i prakse logistike u organizaciji Vojske, radi materijalne, zdravstvene i infrastrukturne podrške.

Transport, kao jednu od funkcija logistike, karakterišu složeni organizacioni i tehnološki procesi. Realizuju se u vrlo kompleksnim uslovima (interakcije vlastitih elemenata i okruženja), uz utrošak resursa (radnih, materijalnih, energetskih, vremenskih i informacionih).

Efikasno funkcionisanje transporta od vitalnog je značaja za sve funkcije logistike u miru i ratu. Kroz iznalaženje novih rešenja organizacionih formi i neprekidno usaglašavanje potreba sa mogućnostima, neophodno je uspostaviti takav dinamički sistem koji će očuvati resurse i potencijale i obezbediti neprekidnost transporta. Transport će biti efikasan primenom načela jedinstvenog logističkog pristupa integracije funkcija logističkih službi prema jedinstvenim ciljevima.

Savremeni rat pred sistem Vojske postavlja niz veoma složenih problema. Povećani su zahtevi za masovnim pokretima jedinica $i$ transportom na ograniče- 


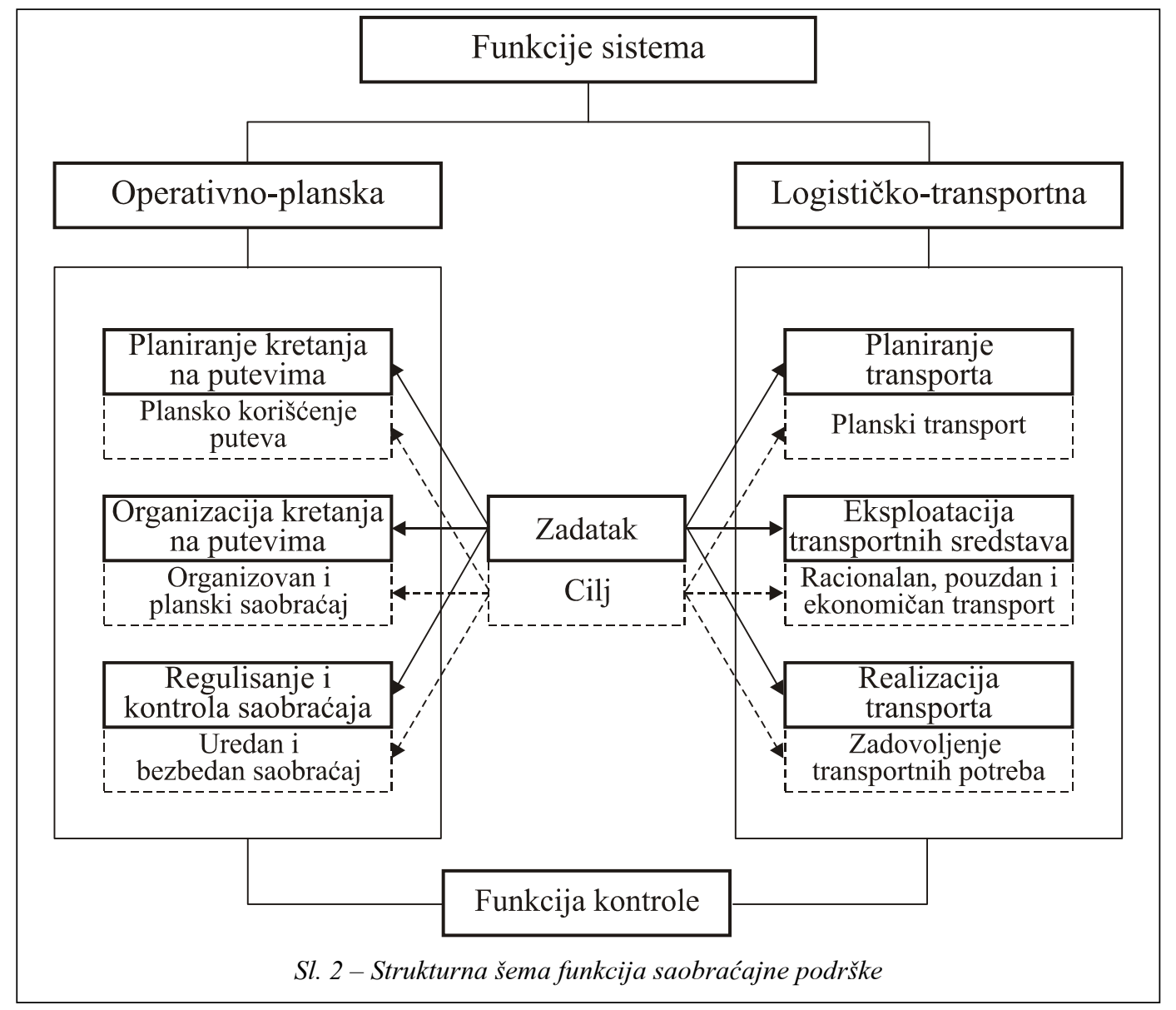

noj putnoj mreži u ograničenom vremenu što se direktno odražava na odbrambenu moć i uspeh tokom izvođenja operacija.

Prema našoj koncepciji odbrane zemlje, posebno se ističe značaj transporta u početnom periodu rata, jer od njegove sposobnosti da izvrši sve zadatke u periodu pripreme i izvođenja mobilizacije direktno zavisi prelazak zemlje na ratno stanje i blagovremeni operativni razvoj jedinica Vojske. To je period u kojem se od transportnog sistema zemlje, a time i od saobraćajne službe Vojske, traži najveći stepen organizovanosti na svim komandnim nivoima. Ta organizacija se $u$ miru mora postaviti i pripremiti tako da bez većih problema i uz što manje promene nastavi funkcionisanje u ratu.

Koncepcija razvoja transportnog sistema zemlje postavljena je, pre svega, radi opštih i privrednih potreba u miru, ali i sa naglašenom potrebom da takav sistem ostane i u ratu. Značajno je istaći da se u ratnim pripremama mora posvetiti pažnja svim granama transporta, prema njihovoj ulozi i mogućnostima u ratu. To nameće potrebu za stalnim jačanjem materijalno-tehničke baze, usavršavanjem organizacijsko-kadrovske strukture i njenog prilagođavanja zahtevima ratne organizacije. 
Ratne pripreme transporta imaju i materijalno-tehničku komponentu, sprovode se u celokupnom sistemu i na čitavoj teritoriji. Organizacija i pripreme vrše se na osnovu procena kojima se utvrđuju karakter i obim rada svih komponenti odbrane, a na planu saobraćajne podrške stvara se integracija Vojske i teritorije. Radi toga su definisani prava i obaveze državnih organa, privrednih subjekata i Vojske u vezi s pripremom za rat.

\section{Zaključak}

Odbrana državne zajednice Srbija i Crna Gora je potreba društva i uslov njegove egzistencije i razvoja, a kao takva ona mora biti i efikasna. Suština odbrane je organizovanje, pripremanje i učešće ljudskih i materijalnih potencijala zemlje $\mathrm{u}$ upornom suprotstavljanju neprijatelju od samog početka agresije do konačnog otklanjanja ili prestanka opasnosti za zemlju.

Vojska SCG se razvija na način koji optimalno odgovara potrebama i realnim mogućnostima zemlje, principima međunarodnog prava koji regulišu upotrebu sile i zahtevima koje ističe fizionomija savremenog rata i drugi oblici ugrožavanja bezbednosti. Sistematsko i kontinuirano organizovanje i pripremanje zemlje za odbranu, uz angažovanje svih njenih resursa i potencijala, mora se zasnivati na usklađenim rešenjima i predstavlja kompleksan sistem.

Sistem odbrane zemlje, u uslovima neposredne ratne opasnosti i rata, pred transportni sistem i njegove podsisteme postavlja sve složenije i teže zadatke, što zahteva povećanje efikasnosti njegovog funkcionisanja. Ispunjenje zahteva u skladu sa osnovnim ciljevima za efikasno funkcionisanje transportnog sistema treba da bude stalan proces i predmet interesovanja odgovarajućih institucija i organa.

Nema razvoja transportnog sistema bez razvoja njegove infrastrukture. Specifične i ograničene mogućnosti svakog vida transporta, nemogućnost razvoja novih grana na celokupnom prostoru zemlje, odnosno ratištu, zahtevaju, naročito u širem, a takođe u najužim razmerama, kombinovanje više grana transporta za realizaciju pojedinih prevoženja i drugih zadataka važnih za odbranu zemlje.

Značaj, složenost i izuzetna razuđenost funkcije transporta u Vojsci nameće potrebu za usavršavanjem postojećih i iznalaženjem novih rešenja, njihovih organizacionih formi i pristupa sa aspekta usaglašavanja potreba i mogućnosti, uz primenu teorijskih i iskustvenih saznanja.

Literatura:

[1] Ustavna povelja državne zajednice Srbija i Crna Gora, Službeni list SCG, br. 1/2003, čl. 54, 55 i 56.

[2] Strategija oružane borbe, privremeni materijal, CVŠ VJ, Beograd 1998

[3] Ustav Republike Srbije, Službeni glasnik RS br. 1/1990.

[4] Stišović, M.: Savremeni strategijski sistemi i problemi odbrane malih zemalja, Beograd, 1996.

[5] Zakon o odbrani (Službeni list SRJ, br. 43/94, 11/95).

[6] Petrović, N.: Privrednosistemske pripreme zemlje za eventualni rat, Poslovna politika, Beograd, 1991.

[7] Jovanović, R.: Transportni sistem VJ u funkciji odbrane SRJ, stručni rad, ŠNO, Beograd 2001.

[8] Jeumović, G.: Organizacija sistema saobraćaja i transporta u VJ, seminarski rad, VA, Beograd, 2001. 
Elementi i ciljevi razvoja transportnog sistema

\begin{tabular}{|c|c|c|c|}
\hline $\begin{array}{l}\text { Elementi razvoja } \\
\text { transportnog sistema }\end{array}$ & Dugoročni ciljevi (DP) & Srednjoročni ciljevi (SP) & $\begin{array}{l}\text { Godišnji ciljevi razvoja } \\
\text { (GP) }\end{array}$ \\
\hline $\begin{array}{l}\text { Organizacijsko- } \\
\text { mobilizacijski razvoj }\end{array}$ & $\begin{array}{l}\text { Uraditi prognozu potreba } \\
\text { VSCG za prevoženjima u } \\
\text { miru, MOB periodu i ratu } \\
\text { po organizacionim } \\
\text { jedinicama i strukturi } \\
\text { transporta. Definisati } \\
\text { jedinstveni transportni } \\
\text { sistem VSCG. Povećati } \\
\text { efikasnost mirnodopskog } \\
\text { transporta. }\end{array}$ & \begin{tabular}{|l|} 
Odrediti obim \\
transportnog rada po \\
godinama SP i potrebe \\
preformiranja transportnih \\
jedinica. Podići stručni \\
nivo kadrovske strukture. \\
Utvrditi pravce razvoja \\
dispečerske službe. \\
Osposobiti snabdevačke \\
službe za izvršenje \\
transporta.
\end{tabular} & $\begin{array}{l}\text { Utvrditi obim i stepen } \\
\text { neravnomernosti obrta } \\
\text { tereta na putnoj mreži po } \\
\text { vrstama tereta i nivoima } \\
\text { centralizovanog } \\
\text { transporta. }\end{array}$ \\
\hline Vozni park & $\begin{array}{l}\text { Proučiti pravce razvoja } \\
\text { tehničkog progresa i } \\
\text { industrije transportnih } \\
\text { sredstava. Utvrditi } \\
\text { kriterijum popune } \\
\text { transportnih jedinica. }\end{array}$ & \begin{tabular}{|l|} 
Odrediti konkretne \\
zadatke razvoja voznog \\
parka po tipovima vozila. \\
Utvrditi potrebu za \\
komercijalnim vozilima \\
posebne namene.
\end{tabular} & $\begin{array}{l}\text { Odrediti kriterijume } \\
\text { korišcenja voznog parka. } \\
\text { Utvrditi kapacitet vozila u } \\
\text { stalnoj i privremenoj } \\
\text { eksploataciji. }\end{array}$ \\
\hline $\begin{array}{l}\text { Sredstva integralnog } \\
\text { transporta (IT) i } \\
\text { manipulacije }\end{array}$ & $\begin{array}{l}\text { Utvrditi tendencije } \\
\text { razvoja sredstava IT i } \\
\text { manipulacije i uskladiti } \\
\text { sopstveni razvoj. Povećati } \\
\text { tehnički nivo procesa } \\
\text { manipulacije. }\end{array}$ & $\begin{array}{l}\text { Odrediti potrebna sredstva } \\
\text { po strukturi i broju za } \\
\text { paletizaciju i } \\
\text { kontejnerizaciju. Uskladiti } \\
\text { transportno-manipulativne } \\
\text { jedinice tereta sa } \\
\text { zahtevima IT. }\end{array}$ & $\begin{array}{l}\text { Utvrditi vrste i količine } \\
\text { MTS za ukrupnjavanje i } \\
\text { potreban broj sredstava IT. }\end{array}$ \\
\hline Parkovi motornih vozila & $\begin{array}{l}\text { Utvrditi potrebu za razvoj } \\
\text { infrastrukture u } \\
\text { parkovima motornih } \\
\text { vozila }\end{array}$ & \begin{tabular}{|l|} 
Odrediti potrebe u \\
garažnom prostoru, \\
nadstrešnicama, \\
stajankama, servisima i \\
kontrolno-propusnim \\
stanicama. Utvrditi \\
kriterijume i tipska \\
rešenja. \\
\end{tabular} & $\begin{array}{l}\text { Povećati ispravnost } \\
\text { transportnih sredstava. } \\
\text { Uskladiti osnovno i } \\
\text { tehničko održavanje sa } \\
\text { izvršenjem transportnih } \\
\text { zadataka. }\end{array}$ \\
\hline Utovarno-istovarna mesta & $\begin{array}{l}\text { Odrediti pravce razvoja } \\
\text { strukture i organizacije } \\
\text { utovarno-istovarnih i } \\
\text { pretovarnih mesta. } \\
\text { Utvrditi potrebe izgradnje } \\
\text { infrastrukture u dogovoru } \\
\text { sa organima društva. } \\
\end{array}$ & $\begin{array}{l}\text { Utvrditi zadatke razvoja, } \\
\text { specijalizacije, obima rada } \\
\text { i propusne moći utovarno- } \\
\text { istovarnih mesta za } \\
\text { potrebe VSCG. }\end{array}$ & $\begin{array}{l}\text { Odrediti i uskladiti obrt } \\
\text { tereta, kapaciteta mesta i } \\
\text { voznih parkova. }\end{array}$ \\
\hline $\begin{array}{l}\text { Resursi - potrošna } \\
\text { sredstva }\end{array}$ & $\begin{array}{l}\text { Sagledati energetske } \\
\text { rezerve potrošnih resursa } \\
\text { (goriva, maziva, i dr.). } \\
\text { Utvrditi strukturu resursa i } \\
\text { značajnost za razvoj i } \\
\text { cenu koštanja. }\end{array}$ & $\begin{array}{l}\text { Odrediti potrebe u } \\
\text { potrošnim resursima. } \\
\text { Opremiti i osavremeniti } \\
\text { dispečersku službu. }\end{array}$ & Sniziti cenu transporta. \\
\hline Naučno-istraživački rad & $\begin{array}{l}\text { Utvrditi pravce naučne } \\
\text { organizacije rada } i \\
\text { upravljanja } u \\
\text { transportnom sistemu } \\
\text { VSCG. }\end{array}$ & $\begin{array}{l}\text { Odrediti program NIR za } \\
\text { organizacijsko- } \\
\text { formacijski razvoji razvoj } \\
\text { materijalne baze vojnog } \\
\text { transporta. }\end{array}$ & $\begin{array}{l}\text { Utvrditi naučno- } \\
\text { istraživačke zadatke } \\
\text { razvoja transporta po } \\
\text { ratnoj veštini, sredstvima, } \\
\text { opremi i ekonomici. }\end{array}$ \\
\hline
\end{tabular}




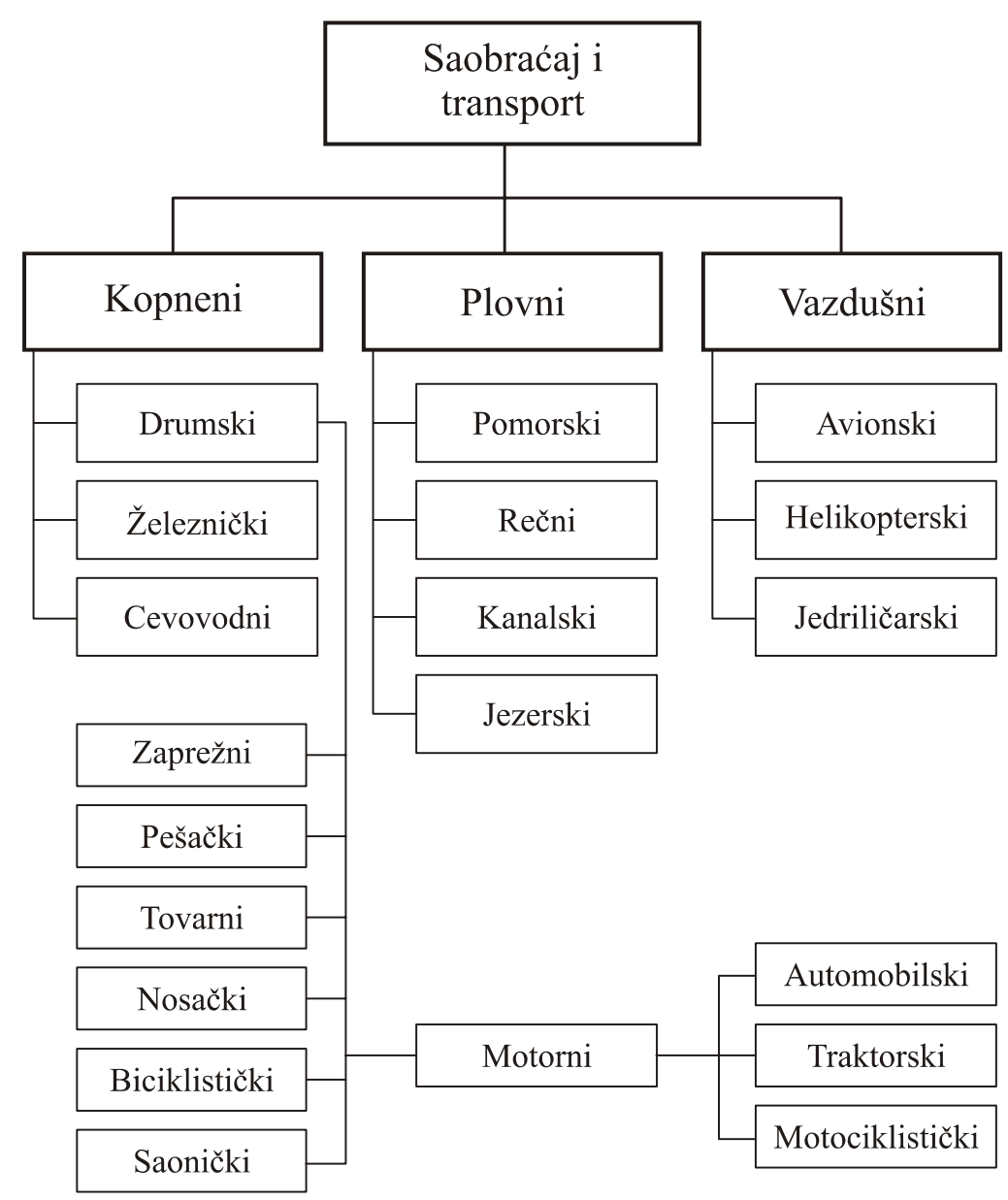




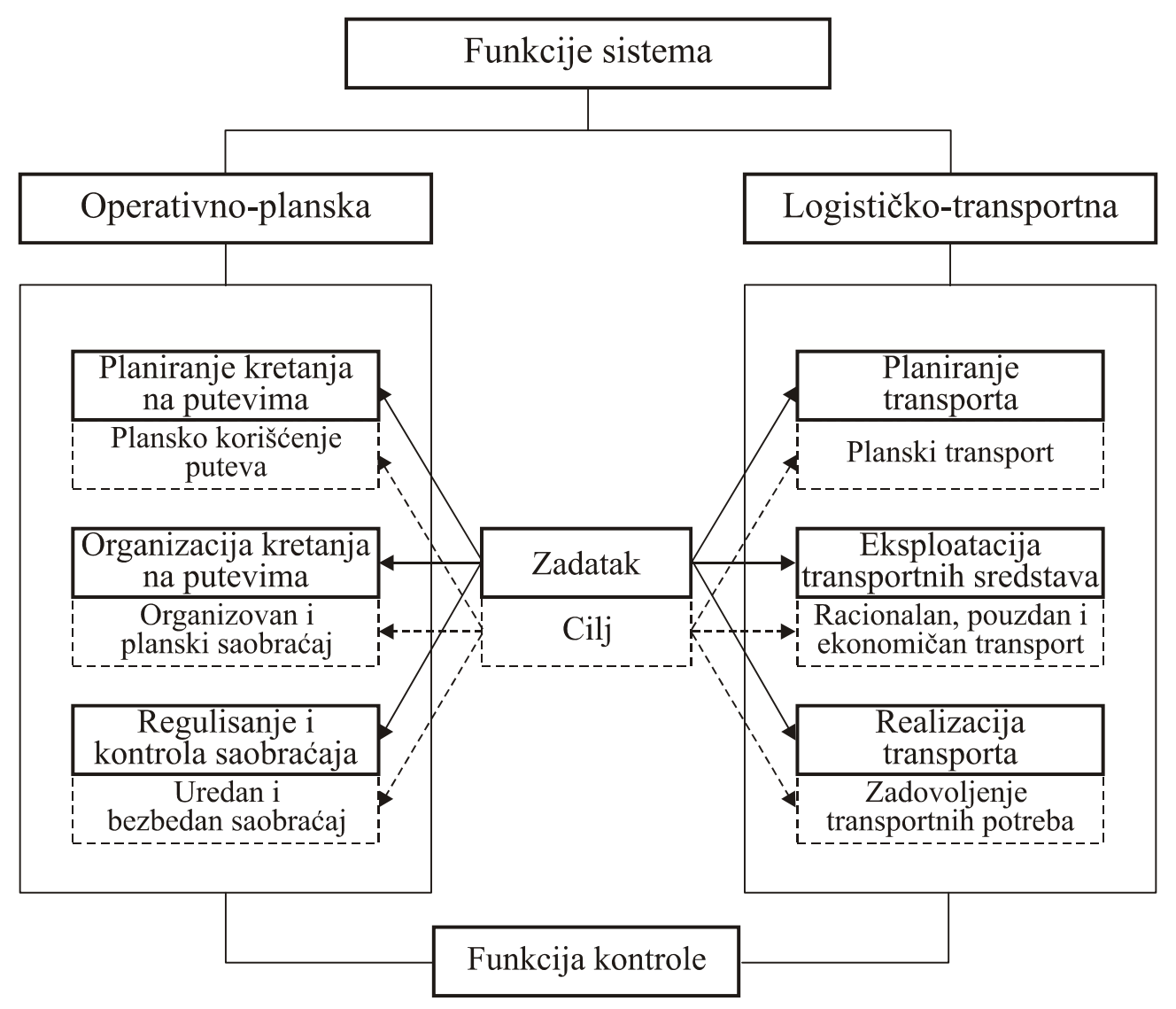

